Explor. Mining Geol., Vol. 10, Nos. 1 and 2, pp. 35-49, 2001 (C) 2002 Canadian Institute of Mining, Metallurgy and Petroleum. All rights reserved. Printed in Canada. 0964-1823/00\$17.00+.00

\title{
Geology of the Palladium-rich Legris Lake Mafic-Ultramafic Complex, Western Wabigoon Subprovince, Northwestern Ontario
}

\author{
NEIL T. PETTIGREW and KÉIKO H. HATTORI \\ Department of Earth Sciences, University of Ottawa and Ottawa-Carleton Geoscience Centre \\ Ottawa, Ontario, Canada, K1N 6N5
}

Received April 2, 2001; accepted September 17, 2002.

\begin{abstract}
The Legris Lake Complex is a northeast-trending, $7.3 \mathrm{~km}$ long by $3.5 \mathrm{~km}$ wide, maficultramafic intrusive complex located in the western Wabigoon Subprovince of the Archean Superior Province. It is one of a series of mafic-ultramafic igneous complexes, the most notable of which is the Lac des Iles Complex, host to Canada's only producing Pd mine with reserves of 93.5 Mt grading $1.53 \mathrm{~g} / \mathrm{t} \mathrm{Pd}$ as of December 2001 (North American Palladium Ltd., Annual Report 2001). Cu-NiPGE mineralization was first discovered in the Legris Lake Complex by a local prospector late in 1999. Shortly thereafter, the property was jointly optioned by Avalon Ventures Ltd. and Starcore Resources Ltd., who continue to discover significant Cu-Ni-PGE mineralization.

One of the most notable features of the Legris Lake Complex is the occurrence of extensive brecciation caused by multiple injections of volatile-rich magma. The Cu-Ni-PGE mineralization is hosted by leucogabbro within a $2 \mathrm{~km}$ long by $600 \mathrm{~m}$ wide, highly brecciated area in the northwestern area of the Complex. The mineralized rocks contain disseminated to blebby sulfides ( 1 to 5 vol. \%), comprising chalcopyrite + pyrite \pm pyrrhotite + millerite \pm pentlandite, typically surrounded by epidote. The majority of the Cu-Ni-PGE mineralization displays low ratios of Pt/Pd $(\sim 0.20)$ and high ratios of $\mathrm{Cu} / \mathrm{Ni}(\sim 2.9)$, which are similar to those of the Lac des Iles and the River Valley mafic-ultramafic complexes. The lithologies in Legris Lake Complex bear similarities to the heterolithic gabbro of the Twilight and Roby Zone deposits at the nearby Lac des Iles mine. However, the mineralization at Legris Lake, which is restricted to leucogabbro overlying unmineralized clinopyroxenite, is similar to that of stratiform deposits such as the Stillwater and Munni Munni complexes. The mineralization at Legris Lake is best explained by the late-stage, immiscible separation of a sulfide melt from volatile-rich parental magmas and the subsequent minor redistribution of metals by deuteric fluids. () 2002 Canadian Institute of Mining, Metallurgy and Petroleum. All rights reserved.
\end{abstract}

\section{Introduction}

The $7.3 \mathrm{~km}$ long by $3.5 \mathrm{~km}$ wide Legris Lake Complex, located $85 \mathrm{~km}$ north of the city of Thunder Bay, is part of the 12680 -acre claim group collectively called the Legris Lake property (Fig. 1). The Legris Lake Complex is located approximately $8 \mathrm{~km}$ southeast of the open pit in the Roby Zone deposit of North American Palladium's Lac des Iles palladium mine (Lavigne and Michaud, this volume). Placer Dome Ltd. entered into an option/joint venture agreement in April of 2001 to spend \$4,000,000 over the next four years to acquire a $50 \%$ interest in the Legris Lake property.

Previous work on the Legris Lake Complex has included: an aeromagnetic survey by the Ontario Department of Mines - Geological Survey of Canada in 1962 (O.D.M. - G.S.C., 1962); regional mapping in 1965 and 1985 (Kaye, 1969; Sutcliffe and Smith, 1988); and airborne

This manuscript was submitted in April 2001 prior to a major exploration program conducted on the Legris Lake Complex in 2001. This has resulted in refining of observations and interpretations presented in this manuscript.
EM and VLF surveys, combined with limited ground-based HLEM, in 1988 by Heenan Senlac Resources Ltd.

Copper-nickel-platinum-group element mineralization was first discovered on the property in the fall of 1999 when Joe Hackl, a local prospector, collected a sample that returned an assay of $3.26 \mathrm{~g} / \mathrm{t}$ combined PGE. The property was subsequently jointly optioned by Avalon Ventures Ltd. and Starcore Resources Ltd. in November 1999, with Avalon Ventures Ltd. acting as the operator of all exploration programs. Avalon Ventures Ltd. commenced line cutting and geophysical surveying in the winter of 1999-2000 and reconnaissance prospecting, stripping, channel sampling, and drilling in the summer of 2000. The initial results were very encouraging with $\mathrm{Cu}-\mathrm{Ni}$-PGE mineralization being intersected beneath the discovery showing in DDH L00-01 (grading $0.61 \mathrm{~g} / \mathrm{t} \mathrm{Pd}, 0.16 \mathrm{~g} / \mathrm{t} \mathrm{Pt}, 0.10 \mathrm{~g} / \mathrm{t} \mathrm{Au}, 0.17 \% \mathrm{Cu}$, and $0.09 \% \mathrm{Ni}$ over $12 \mathrm{~m}$ ) and in DDH L00-02 (grading 1.22 $\mathrm{g} / \mathrm{t} \mathrm{Pd}, 0.24 \mathrm{~g} / \mathrm{t} \mathrm{Pt}, 0.17 \mathrm{~g} / \mathrm{t} \mathrm{Au}, 0.32 \% \mathrm{Cu}$, and $0.10 \% \mathrm{Ni}$ over $10.7 \mathrm{~m}$ ). In addition, a new mineralization, located $500 \mathrm{~m}$ southeast of the original discovery showing, was recognized at the top of DDH L00-04 (grading $0.52 \mathrm{~g} / \mathrm{t}$ 


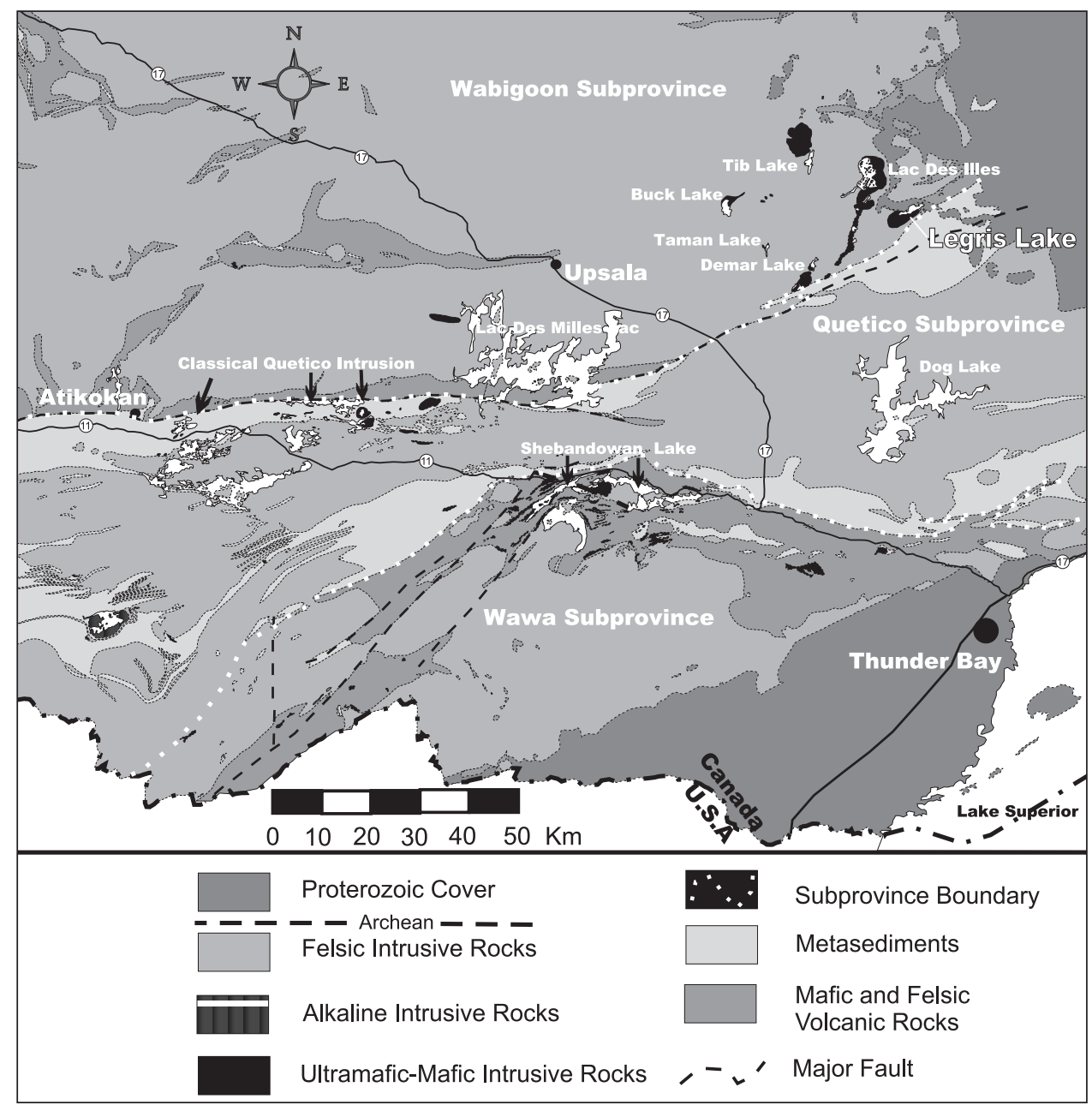

Fig. 1. Location and regional geology map of the Legris Lake Complex. Modified after Pye and Fennwick (1964).

$\mathrm{Pd}, 0.16 \mathrm{~g} / \mathrm{t} \mathrm{Pt}, 0.19 \mathrm{~g} / \mathrm{t} \mathrm{Au}, 0.28 \% \mathrm{Cu}$, and $0.07 \% \mathrm{Ni}$ over $4.70 \mathrm{~m}$ ).

An extensive exploration program consisting of additional line cutting, geophysical surveying, prospecting, grid mapping, and diamond drilling was completed in the fall of 2000. This also yielded encouraging results, for example, DDH L00-08 cut three separate mineralized sections: $2.04 \mathrm{~g} / \mathrm{t} \mathrm{Pd}, 0.41 \mathrm{~g} / \mathrm{t} \mathrm{Pt}, 0.71 \mathrm{~g} / \mathrm{t} \mathrm{Au}, 0.42 \% \mathrm{Cu}$, and $0.013 \%$ $\mathrm{Ni}$ over 9.95 m; 1.94 g/t Pd, 0.34 g/t Pt, 0.64 g/t Au, 0.29\% $\mathrm{Cu}$, and $0.11 \% \mathrm{Ni}$ over $3.80 \mathrm{~m}$; and $1.32 \mathrm{~g} / \mathrm{t} \mathrm{Pd}, 0.27 \mathrm{~g} / \mathrm{t} \mathrm{Pt}$, $0.30 \mathrm{~g} / \mathrm{t} \mathrm{Au}, 0.33 \% \mathrm{Cu}$, and $0.10 \mathrm{Ni}$ over $3.00 \mathrm{~m}$. In addition, a third zone of $\mathrm{Cu}-\mathrm{Ni}-\mathrm{PGE}$ mineralization was discovered $500 \mathrm{~m}$ northeast of the original discovery showing (termed the Main Showing, Fig. 2) during prospecting. The vertical extent of this third zone was tested by DDH L00-07, which intersected a mineralization grading $0.96 \mathrm{~g} / \mathrm{t} \mathrm{Pd}, 0.15 \mathrm{~g} / \mathrm{t} \mathrm{Pt}$, $0.10 \mathrm{~g} / \mathrm{t} \mathrm{Au}, 0.13 \% \mathrm{Cu}$, and $0.04 \% \mathrm{Ni}$ over $4.92 \mathrm{~m}$. Expenditures as of December 2000 on the property by the Avalon/Starcore joint venture total approximately $\$ 400,000$. A more detailed description of the exploration history of the Legris Lake Complex appears in Pettigrew $(2000,2002)$ and that of the mineralization in Pettigrew and Hattori (2002).

\section{Regional Geology}

The Legris Lake Complex is situated in the southern Wabigoon Subprovince of the Archean Superior Province (Fig. 1). It is one of a series of mafic-ultramafic intrusions that form a circular pattern approximately $30 \mathrm{~km}$ in diameter (Sutcliffe, 1986), which includes the PGE-bearing Lac des Iles Complex, the Tib Lake intrusion, Demars Lake intrusion, Wakinoo Lake intrusion, Towle Lake intrusion, Buck Lake intrusion, the Taman Lake intrusion, and the Dog River intrusion (Fig. 1).

\section{Deformation and Metamorphic History}

Structural studies of supracrustal rocks completed elsewhere in the Wabigoon Subprovince suggest the occurrence of three deformation events in the area (Blackburn et al., 1991). Steeply plunging early folds, $\left(D_{1}\right)$, were refolded with an easttrending axis of unknown plunge, $\left(\mathrm{D}_{2}\right)$, and both of these folds were refolded about northeast-plunging axes during the emplacement of the adjacent granitoid rocks, $\left(D_{3}\right)$, (Blackburn 


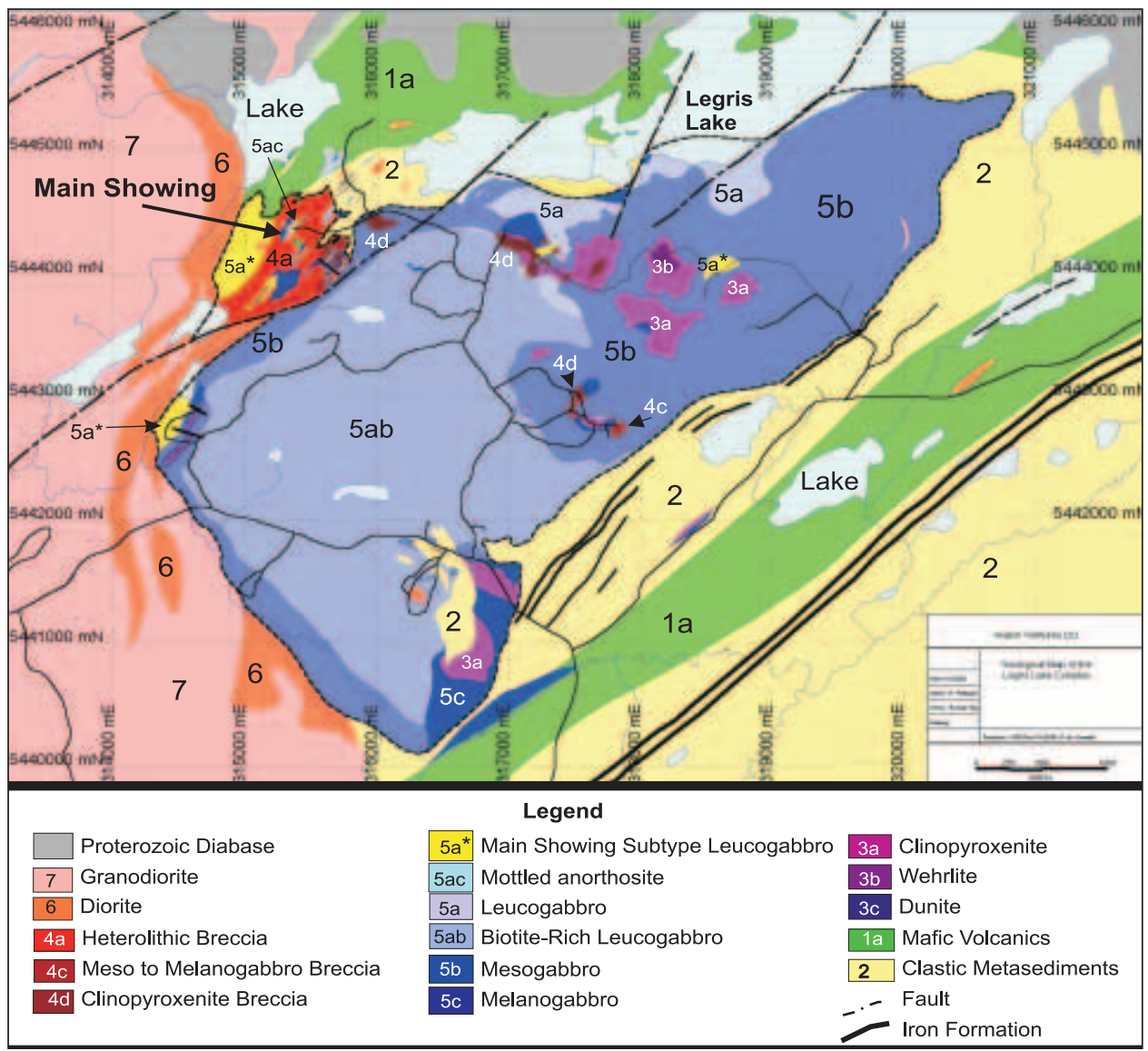

Fig. 2. Geological map of the Legris Lake Complex. This map was produced after the completion of the 2001 exploration program on the Legris Lake Complex.

et al., 1991). The supracrustal rocks have undergone greenschist facies regional metamorphism with middle amphibolite grade around the late granitoid batholiths (Ayres, 1978) after the major episode of folding (Poulsen et al., 1980).

\section{Intrusions}

Granitic rocks in the Wabigoon Subprovince have been subdivided into three groups (Blackburn et al., 1991):

1. The tonalitic igneous rocks ( $\operatorname{circa} 3 \mathrm{Ga}$ );

2. Granitoid complexes (2732 Ma to $2708 \mathrm{Ma}$ ), with Na-rich marginal phases, which are accompanied by rare mafic to ultramafic stocks. These granitoids are associated with comagmatic volcanic rocks (Davis et al., 1982; Edwards and Davis, 1984); and

3. Post-tectonic granitoid stocks (2709 Ma to $2685 \mathrm{Ma}$ ), in and marginal to the greenstone belts. The voluminous, late granodiorite pluton located to the west of the Legris Lake Complex belongs to this group.

Mafic-ultramafic intrusions in the Wabigoon Subprovince are subdivided into three groups (Blackburn et al., 1991):

1. Serpentinized ultramafic intrusions, such as the Chrome Lake-Puddy Lake intrusion, which are interpreted to have been emplaced in a manner similar to that of Phanerozoic, Alpine-type intrusions (Whittaker, 1980);

2. Synvolcanic sills, such as the Bad Vermilion and Mulcahy intrusions; and

3. Mafic to ultramafic intrusions of largely tholeiitic character (Blackburn et al., 1991; Sutcliffe et al., 1989) that are associated with the post-tectonic granitoids emplaced at circa $2.69 \mathrm{Ga}$. The Legris Lake Complex belongs to this group, which also includes the Lac des Iles Complex of 2692 $2_{-2}$ (Davis and Edwards, 1986; Sweeny and Sutcliffe, 1986) and the Entwine Lake intrusion (Davies, 1965).

\section{Geology of the Legris Lake Area}

\section{Country Rocks}

Metasedimentary rocks (unit 2). Sandstone (unit 2b) is the most common sedimentary rock in the area. It consists of fine- to medium-grained, arkose to graywacke that has a dull light brown color in the field. This unit always displays a well-developed space cleavage and commonly contains red garnet close to the contact with the Legris Lake Complex, indicating that it has undergone at least lower amphi- 

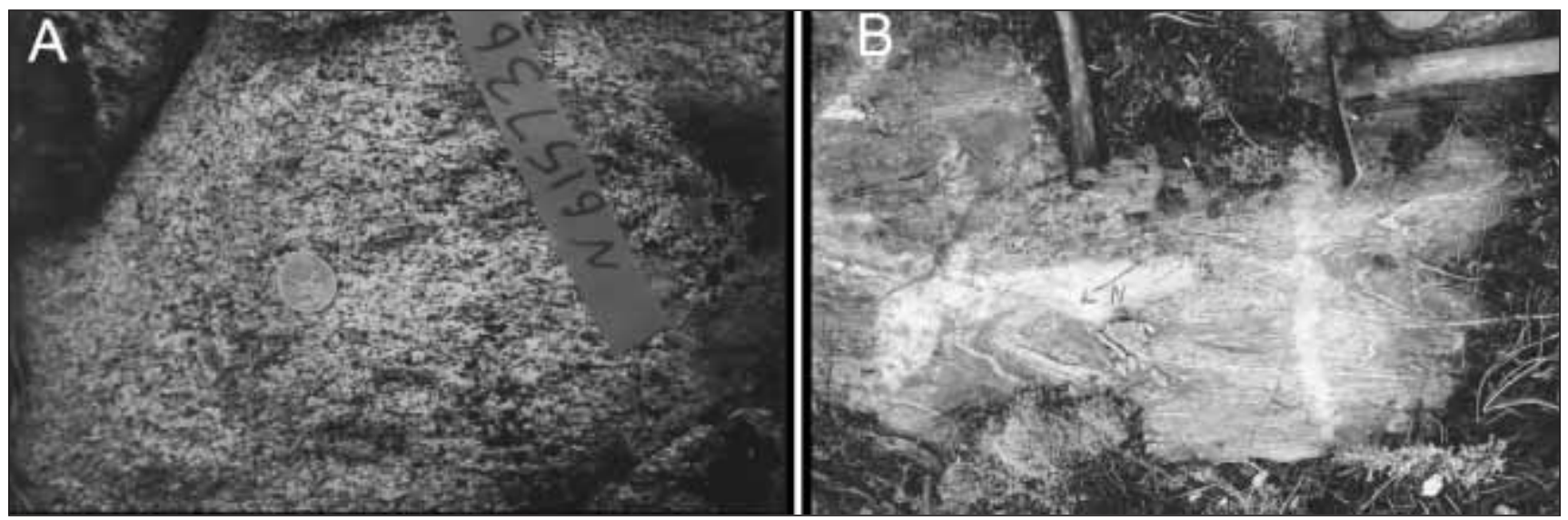

Fig. 3. (A) Foliated granodiorite country rock, from the western side of the Legris Lake Complex. (B) Quartz arenite country rocks, located in the Northwestern Border area, displaying strongly folded quartz veins.

bolite facies contact metamorphism. Poorly sorted pebble to cobble conglomerate (unit 2a), with a graywacke matrix, is common in the western part of the area. Clasts of the conglomerates are well rounded and comprise a variety of rock types including sedimentary, volcanic, and dioritic and granitic rocks. A low to moderate degree of flattening of the clasts is common. Minor siltstone to pelitic beds (unit 2c) and thin oxide facies (magnetite) iron formations are commonly interbedded within sandstone beds.

Basaltic rocks (unit 1a). Voluminous mafic volcanic rocks occur both north and southeast of the Complex. This fine-grained unit display a good space cleavage, and is generally non-magnetic in character.

Granitic rocks (units 7 and 6). Granitic rocks in the area range in composition from tonalite to granite, with minor diorite, and are associated with the intrusion of the voluminous granodiorite pluton west of the Legris Lake Complex. Medium-grained granodiorite (Fig. 3A) is the most common intrusive rock type in contact with the western and southern parts of the Legris Lake Complex. It contains $\sim 50$ vol. $\%$ plagioclase, $\sim 25$ vol.\% quartz, $\sim 10$ vol. $\%$ hornblende, $\sim 15$ vol. $\%$ biotite, and variable amounts of magnetite. The marginal phase of the pluton displays moderate to strong foliation defined by the preferred orientation of biotite and is strongly magnetic with high contents of magnetite, whereas, the interior of the pluton is massive and non-magnetic. Numerous dikes and sills of the granodiorite pluton cut (and postdate) the Legris Lake Complex.

\section{Deformation of the Country Rocks}

The Legris Lake area records two regional deformation events. The earlier event formed a northeast-striking, southeast-dipping, space cleavage under greenschist facies metamorphic condition. This space cleavage is parallel to the Wabigoon-Quetico Subprovince boundary and most likely formed during the accretion of the Quetico onto the Wabigoon Subprovince. Primary sedimentary textures, such as slumping and cross-bedding, are commonly preserved in the country rocks; however, the deformation intensifies proximal to the Legris Lake Complex where local penetrative foliations, mineral lineation, and tight chaotic folds are well developed and likely developed under amphibolite facies metamorphic conditions (Fig. 3B). The occurrence of areas of intense deformation with attendant amphibolite grade metamorphism, only in the areas proximal to the Legris Lake Complex, suggests that they formed during the intrusion of the Complex.

A later north-south trending fracture set, formed under sub-greenschist facies conditions, overprints all other structures in the Archean rocks in the area.

\section{Dikes in the Legris Lake Complex}

Granodiorite dikes, related to the voluminous granodiorite pluton, lack a space cleavage and are commonly associated with narrow feldspar-quartz pegmatites and retrograde alteration halos in the Complex. Quartz-feldspar porphyry dikes (unit 7d) are distinguished from the more abundant granodiorite dikes. The quartz-feldspar porphyry dikes are narrow ( $<3 \mathrm{~m}$ wide), of limited length, and only observed in the northwestern area of the Legris Lake Complex. They are typically medium-grained $(\sim 2 \mathrm{~mm})$, non-magnetic, and quartz-rich ( 40 vol.\%), with few mafic minerals ( $<5$ vol.\%). The quartz-feldspar porphyry dikes lack wide alteration halos and their intrusion post-dated the majority of the deformation in the Legris Lake Complex. The evidence suggests that the felsic dikes are similar in age, and cross-cutting relationships among different dikes are not observed.

Rare melanogabbro dikes also cut the northwestern part of the Complex and have also been observed to cut the voluminous granodiorite pluton. The dikes, dubbed the Stonefish Lake sub-type, are medium- to coarse-grained, consisting of elongate plagioclase phenocrysts (up to $1 \mathrm{~cm}$ by $2 \mathrm{~mm}$ ) set in a fine-grained, biotite-bearing matrix. The melanogabbro dikes locally contain thin $(\sim 2 \mathrm{~cm})$ magnetite-rich lenses. 
The Legris Lake Complex is also cut by rare Keweenawan $(\sim 1.1 \mathrm{Ga})$ diabase dikes and sills. A few erosional remnants of previously overlying diabase sills are found on nearby Archean rocks (Fig. 2).

\section{Overburden}

The area has been glacially scoured, leaving consistent glacial striations with an orientation of $\sim 245^{\circ}$. The property is covered by basal and ablation till, which is in turn overlain by glaciofluvial deposits. The rock exposure in the northwestern part of the Complex comprises less than $3 \%$ of the area, as it is evenly covered by basal and ablation tills, small eskers, and several large boulder-strewn bogs. The western and southwestern parts of the Complex also have poor rock exposure ( $<5 \%$ of the area), being covered by a combination of glaciofluvial gravel and cobbles, several large eskers, and paleo-delta deposits. The center of the Complex has better exposure ( $20 \%$ of the area) with less than $1 \mathrm{~m}$ of overburden. The eastern part of the Complex has very poor exposure $(<1 \%$ of the area) and thick $(>3 \mathrm{~m})$ overburden consisting of glaciofluvial sand and several large gravel eskers.

\section{The Legris Lake Mafic-Ultramafic Complex}

The distribution of mafic-ultramafic intrusions in the area suggests that the Legris Lake Complex (Fig. 1) was most likely emplaced contemporaneously with the Lac des Iles mafic-ultramafic complex of $2692^{+4 /-2}$ (Davis and Edwards, 1986). The Legris Lake Complex comprises a wide range of intrusive rock types: from leucogabbro to dunite in composition, with biotite-rich leucogabbro (unit $5 \mathrm{ab}$ ) being the predominant rock type (Fig. 2). Based on the distribution of lithological units, the Complex is divided into five areas: the Central, Northwestern Border, Southwestern Border, Northeastern Border, and Southeastern Border areas (Fig. 2). The Central area, located in the core of the Complex, is composed almost entirely of biotite-rich leucogabbro (unit 5ab; Figs. 2, 4 and 5) that locally contains up to 10 vol.\% quartz.

The Northwestern Border area is economically important since it hosts all of the $\mathrm{Cu}-\mathrm{Ni}$-PGE mineralization discovered to date (Figs. 2 and 5). Geological mapping in this area was hindered by the poor rock exposure, the heterogeneity of the lithologies, and the apparent disagreement between the nature of the exposed rocks and the attendant geophysical signatures. To investigate the geology of the Northwestern Border area, $540 \mathrm{~m}$ of trenching were completed. The trenching revealed the complicated and unpredictable distribution of rock types. Lithologies commonly change over distances of less than $5 \mathrm{~m}$. Diamond drill holes DDH L00-01, -02, -03, -04, -08, and -09 were drilled along a fence between lines $9500 \mathrm{~N}$ and $9600 \mathrm{~N}$, parallel to the trench, in an attempt to provide sub-surface data for the area (Fig. 6). The diamond drilling revealed that the complexity observed on surface is also present at depth. Although trench and drill sections generally did not correlate, mineralized leucogabbro displayed good down-dip continuity. The Northwestern Border area appears to have a very moderate to steep boundary with the mesogabbro (unit 5b) and leucogabbro (unit 5ab) of the Central area of the Complex, with the boundary being located between DDH L00-08 and L00-09 (Fig. 6).

The complicated interaction of melt, semi-solidified crystal mush, and solidified magmas has produced various textures and structures such as the local alignment of minerals and fragments, and shearing, in the Legris Lake Complex. The shear sense is mostly sinistral and may have been influenced by contemporaneous regional deformation. Small- to medium-scale folding is also observed, although these structures display no consistent patterns. These structures are commonly present in the form of ductile $\mathrm{S}$ folds, but also occur as discordant open undulating folds, and as rare refolded folds.

The Southwestern Border area is characterized by the second largest body of leucogabbro (unit $5 \mathrm{a}^{*}$ ), and also by the lack of any heterolithic breccia. It exhibits a less complicated assemblage of lithologies and structures than the Northwestern Border area (Figs. 2 and 5). It also hosts a magnetite-rich, zoned ultramafic dike, which is not exposed on surface, but was intersected by DDH L00-06.

The Northeastern Border area comprises most of the northeastern half of the Legris Lake Complex (Fig. 2). It consists mostly of mesogabbro but also contains several large (up to $600 \mathrm{~m}$ by $400 \mathrm{~m}$ ) ultramafic (units $3 \mathrm{a}$ and $3 \mathrm{~b}$ ) bodies, large metasedimentary xenoliths or roof pendants, and a large zone of clinopyroxenite breccia (unit 4d), with the latter unit being similar to that of the Lac des Iles mine. This area has the poorest exposure of the five areas, and therefore much of the geological interpretation of the area is based primarily on geophysical data. This area has received only reconnaissance prospecting and mapping.

The Southeastern Border area $(1.8 \mathrm{~km}$ by $1.0 \mathrm{~km})$ consists of rock types ranging from biotite-rich leucogabbro (unit $5 \mathrm{ab}$ ) to poikilitic clinopyroxenite, with minor igneous breccia, which are in contact with country, clastic metasedimentary rocks with thin, interbedded oxide facies iron formations (Fig. 2). The area is characterized by the presence of large (up to $1.0 \mathrm{~km}$ by $0.3 \mathrm{~km}$ ) metasedimentary roof pendants (Fig. 2). The roof pendants appear to represent a thin veneer as several windows expose the underlying gabbroic rocks, and the metasedimentary rocks of the roof pendants show evidence of partial melting. The tectonic fabric that is common in metasedimentary country rocks has been obliterated. Most metamorphic minerals appear to have been retrograded to biotite with only a few garnets remaining. This area possesses a distinct type of igneous breccia consisting of coarse-grained clinopyroxenite broken up on a mineral scale by a dioritic to granodioritic matrix. This area has also received only reconnaissance prospecting and mapping. 

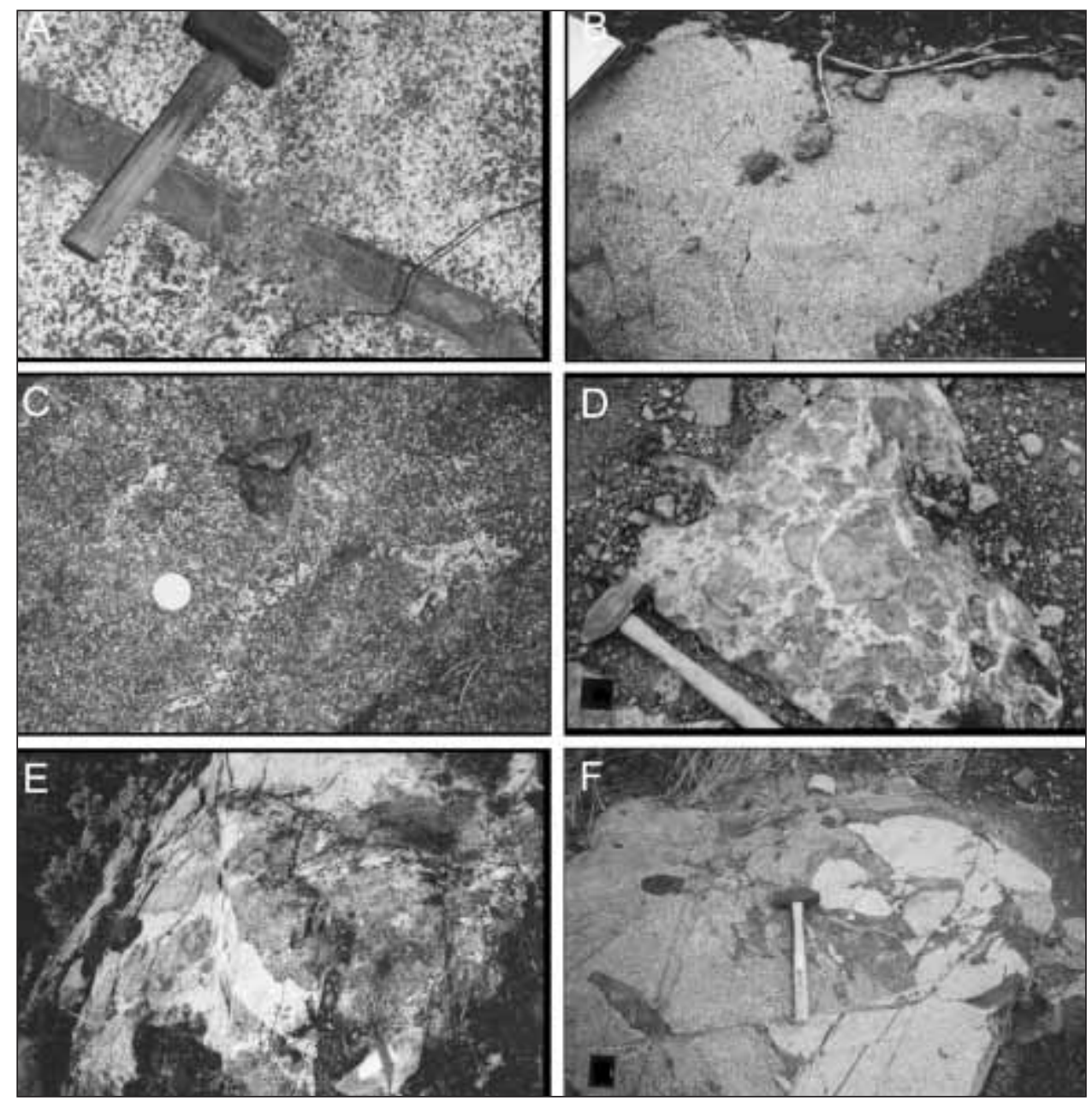

Fig. 4. (A) Leucogabbro (unit 5a*) with late cross-cutting mafic dike, from the Northwestern Border area. (B) Biotite rich leucogabbro (unit 5ab), with late cross-cutting mafic dike, from the center of the Legris Lake Complex. (C) Melanogabbro (unit 5c) from the Eastern Border area. (D) Heterolithic breccia (unit 4a) from the Northwestern Border area. (E) Leucogabbro (unit 5a*) brecciated by finegrain magnetite-rich leucogabbro near DDH L00-07. (F) Clinopyroxenite breccia (unit 5d) from the Northwestern Border area.

Leucogabbro (unit 5a). This unit contains many different phases and has been further divided into four subtypes (Figs. 2, 5, and 6):

1. Main Showing sub-type (unit 5a*). This sub-type hosts nearly all of the $\mathrm{Cu}$-Ni-PGE mineralization discovered thus far in the Complex. It is easily identified in the field by its striking white plagioclase phenocrysts and black to dark green interstitial clinopyroxene that is altered to hornblende (Fig. 4A). Unit 5a* is medium- to coarse-grained (4 $\mathrm{mm}$ to $8 \mathrm{~mm}$ ), and composed of $\sim 65 \mathrm{vol} . \%$ plagioclase, $\sim 35 \mathrm{vol} . \%$ clinopyroxene (typically altered and pseudomorphed by hornblende), 1.5 vol.\% quartz, up to 3 vol.\% magnetite, with trace amounts of apatite and zircon. Apatite contents are as high as $5 \mathrm{vol} . \%$ in some samples of unit $5 \mathrm{a}^{*}$. This unit has been brecciated locally by the intrusion of fine-grained, magnetite-rich leucogabbro and melanogabbro.

2. Varitextured sub-type (unit 5aa). This sub-type exhibits a wide variation in the size and shape of plagioclase phenocrysts and locally contains fine- to coarse-grained pegmatitic pods. It grades into the leucogabbro of the Main Showing sub-type (unit 5a*) in several locations. Unit 5aa also locally contains $\mathrm{Cu}-\mathrm{Ni}$-PGE mineralization, and is similar in texture and composition to the varitextured gabbro unit of the Lac des Iles Complex (see Lavigne and Michaud, this volume).

3. Biotite-rich sub-type (unit 5ab). This sub-type occurs in the center of the Complex. It is massive with locally weak fabric development, and contains abundant primary and secondary biotite (Fig. 4B). Unit 5ab is typically mediumgrained ( $2 \mathrm{~mm}$ to $4 \mathrm{~mm}$ ), and consists of plagioclase ( $\sim 60$ vol.\%), altered clinopyroxene ( 25 vol. $\%)$, quartz $(<5$ vol.\%), biotite (>10 vol.\%), and apatite ( $<5$ vol. \%). Primary clinopyroxene is entirely replaced by secondary hornblende, and locally by secondary biotite. Unit $5 \mathrm{ab}$ has undergone intense saussuritization of feldspar, and developed large patches (tens of meters in size) of orange hematitic alteration; it is moderately magnetic to non-magnetic depending on the degree of feldspar alteration. No Cu-Ni-PGE miner- 


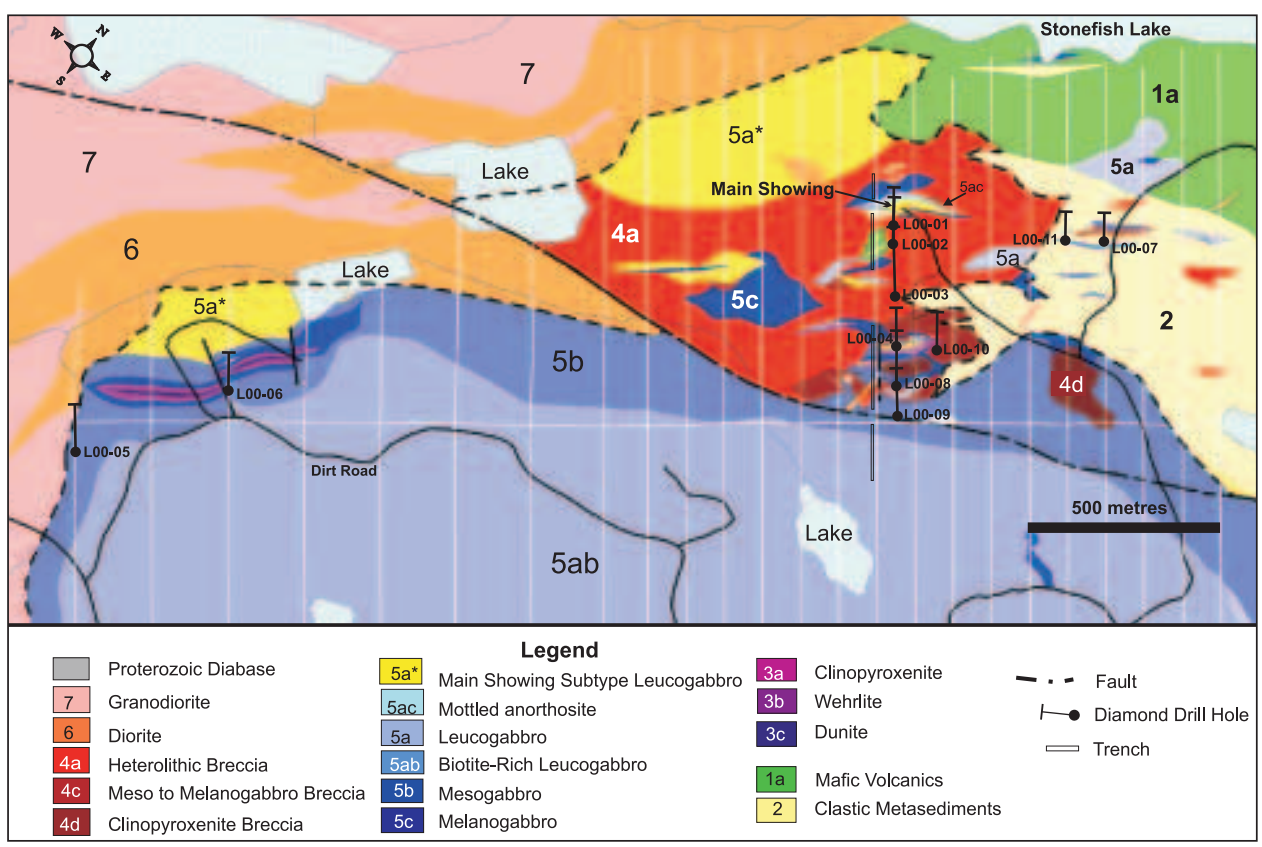

Fig. 5. Geological grid map of western part of the Legris Lake Complex. This map was produced after the completion of the 2001 exploration program on the Legris Lake Complex, however, only holes mentioned in this manuscript are shown for simplicity.

alization has yet been discovered in unit $5 \mathrm{ab}$, but pyrite (up to 2 vol.\%) may be present locally.

4. Mottled Anorthosite (unit 5ac). This sub-type is found predominantly in the Northwestern Border area of the Complex. The most voluminous occurrence is at the Main Showing, where it forms a thick unit in contact with the mineralized Unit 5a* leucogabbro (Fig. 4A). The anorthosite possibly represents a more fractionated phase of the leucogabbro. It is medium- to coarse-grained, composed of highly saussuritized plagioclase with interstitial clinopyroxene mottles, which occasionally contain disseminated magnetite, and generally non-magnetic. The clinopyroxene mottles define a foliation in the Main Showing. They have been completely altered to hornblende and subsequently to chlorite \pm biotite. Although $\mathrm{Cu}-\mathrm{Ni}$-PGE mineralization (up to 200 ppb PGE) has been intersected by diamond drilling in this rock type at the Main Showing, this unit is generally unmineralized.

Mesogabbro (unit 5b). This is primarily a transitional unit between the biotite-rich leucogabbro (unit 5ab) and the melanogabbro (unit 5c).

Melanogabbro (unit 5c). The melanograbbro unit contains several phases, all of which are medium-grained $(\sim 3 \mathrm{~mm})$, with abundant plagioclase and clinopyroxene that is altered to hornblende (Fig. 4C). This unit commonly grades into clinopyroxenite (Figs. 2 and 5) and is typically strongly magnetic because of the occurrence of up to 15 vol.\% interstitial magnetite. It may contain sulfide minerals (up to 3 vol.\%) as blebs of pyrrhotite and pyrite, some of which contain chalcopyrite as an exsolved phase. Rocks of unit 5c in DDH L00-08 are intensely chloritized with locally high concentrations of $\mathrm{Cu}$ (up to $760 \mathrm{ppm}$ ) and $\mathrm{Ni}$ (up to 256 ppm), but low contents of PGE (typically $<5 \mathrm{ppb}$, with one anomalous sample with 100 ppb PGE).

Clinopyroxenite (unit 3a). This medium- to very coarse-grained, moderately to strongly magnetic unit is common near the western contact of the Legris Lake Complex (Figs. 2 and 5) where it commonly grades into melanogabbro. The clinopyroxene is mostly altered to a mixture of hornblende, actinolite, and chlorite. Although no $\mathrm{Cu}-\mathrm{Ni}$-PGE mineralization has been discovered in this unit, it is always in contact with mineralized leucogabbro of unit $5 \mathrm{a}^{*}$, a spatial relationship that suggests that the two units are likely related.

Wehrlite (unit 3b) and Dunite (unit 3c). Both units are only observed in DDH L00-06, where they grade into one another as the content of clinopyroxene varies. They are typically fine- to medium-grained ( $1 \mathrm{~mm}$ to $3 \mathrm{~mm}$ ) rocks composed of clinopyroxene, olivine, and magnetite ( 10 vol.\%). The clinopyroxene is altered to hornblende and minor actinolite. All former olivine grains are serpentinized, forming net-textured grains with patches of magnetite. Neither unit has any associated PGE mineralization. Low Ni contents $(<335 \mathrm{ppm})$ in the dunite suggest that Ni may have been removed by the separation of sulfide melt from the parental magma before the crystallization of olivine.

Heterolithic breccia (unit 4a). This is the most common type of breccia in the Legris Lake Complex (Fig. 4D), forming a $600 \mathrm{~m}$ by $2 \mathrm{~km}$ wide feature in the Northwestern Border area (Figs. 2 and 5), over which the metasedimentary country rocks grade into the breccia unit. The breccia contains abundant partially assimilated metasedimentary rocks, minor gabbroic rocks, and exotic rocks that are not exposed in the Legris Lake area. The matrix of the heterolithic breccia varies 


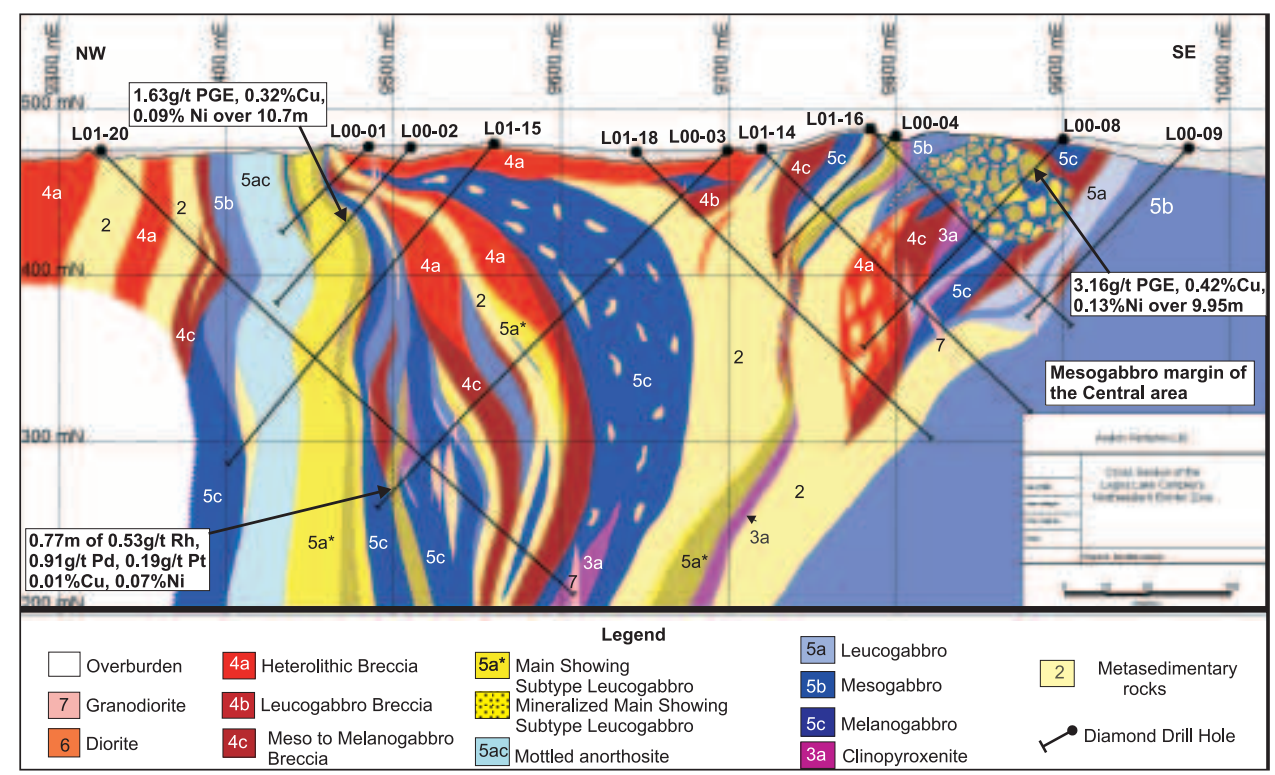

Fig. 6. Diamond drill hole cross-section across the Northwestern Border zone of the Legris Lake Complex. This cross-section was produced after the completion of the 2001 exploration program on the Legris Lake Complex. All hole labels L01-\#\# were drilled during 2001.

in composition from that of quartz diorite, to leucogabbro, to granodiorite. Fragments of metasedimentary rocks have undergone retrograde alteration subsequent to brecciation, typically resulting in the transformation of garnet to biotite.

The heterolithic breccia (unit $4 \mathrm{a}$ ) has been intruded by several later gabbroic phases. All of the mineralized leucogabbro (i.e., Main Showing sub-type of unit 5a*) is spatially associated with the heterolithic breccia. The breccia unit may represent the product of the incorporation of a thin veneer of sedimentary rocks that formerly overlay the Legris Lake Complex, an interpretation that is supported by the exposure of a large finger of metasedimentary rocks extending into the heterolithic gabbro from the north-northwest contact of the intrusion (Fig. 2). Alternatively, the heterolithic breccia unit may represent the remnants of a structural corridor, located along the northwest margin of the Legris Lake Complex, exploited by intruding magmas and escaping volatiles in a manner similar to the formation of the heterolithic gabbro at Lac des Iles and the breccia zone lining the western contact at the River Valley intrusion.

Leucogabbro breccia (unit $\mathbf{4 b}$ ). This unit, which is defined as a breccia with predominantly gabbroic clasts set in a leucogabbroic matrix, is relatively uncommon. In DDH L 00-07, rocks of this unit contain Cu-Ni-PGE mineralization. Here the mineralized unit contains chloritized clasts of leucogabbro (unit 5a*) and a fine-grained, magnetite-rich leucogabbroic matrix. Both the clasts and matrix are mineralized.

Meso- to melanogabbro breccia (unit 4c). Common in the Legris Lake Complex (Figs. 2 and 5), this unit appears to be more abundant at deeper levels in the Northwestern Border area than on the surface (Fig. 6). Typically, clasts of predominantly gabbroic composition are set in a matrix of mesocratic to melanocratic gabbro, although clasts of metasedimentary country rock are also common in the Northwestern Border area.

Clinopyroxenite breccia (unit 4d). This unit contains predominantly gabbroic clasts set in a clinopyroxenite matrix (Figs. 4F, 5), and is very similar to the igneous breccia at Lac des Iles. Another type of clinopyroxenite breccia is found near the eastern contact of the Complex. The latter type consists of fractured clinopyroxenite clasts set in a matrix of plagioclase and quartz.

\section{Alteration in the Legris Lake Complex}

The Legris Lake Complex displays at least two stages of alteration: deuteric alteration associated with the intrusion of the Complex and retrograde alteration associated with the emplacement of late granitoid bodies. Deuteric alteration took place during successive phases of injection and solidification of mafic magma in the Complex, and resulted in: 1) the uralization of clinopyroxene to produce hornblende, and the serpentinization of olivine; 2) the formation of an early, dark-green mixture of epidote \pm actinolite surrounding chalcopyrite blebs; 3 ) biotite alteration of hornblende, and the destruction of garnet in metasedimentary xenoliths; 4) minor sericitization and saussurization of plagioclase; and 5) intense chloritization of gabbroic phases and actinolite alteration of secondary hornblende after clinopyroxene.

Local retrograde alteration under regional greenschist facies conditions occurred contemporaneously with the intrusion of granitic and dioritic dikes in the Legris Lake Complex. This event caused widespread saussurization and hematitic alteration of plagioclase, and the destruction of magnetite in the mafic-ultramafic rocks. Biotite alteration 

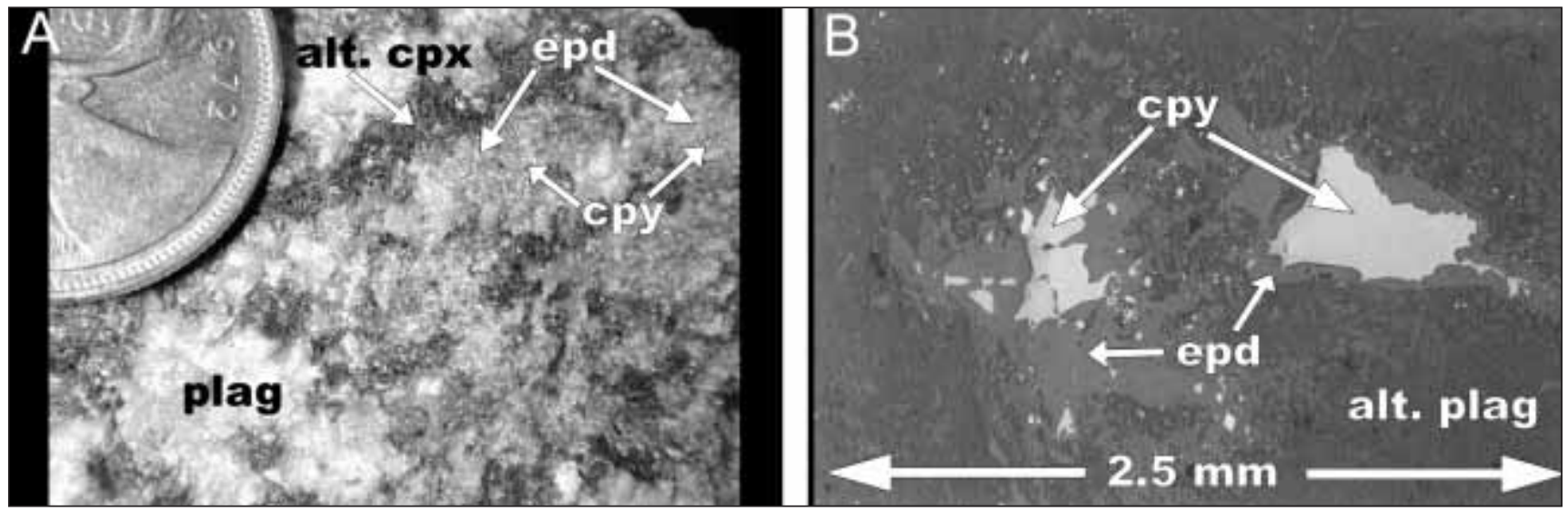

Fig. 7. (A) Hand sample of mineralized leucogabbro (unit 5a*) displaying dark-green epidote alteration surrounding Cu-Ni sulfides. (B) Reflected light photomicrograph of chalcopyrite surrounded by epidote in leucogabbro (unit 5a*) from DDH L00-01. plag = plagioclase, cpx = clinopyroxene, epd $=$ epidote, cpy $=$ chalcopyrite .

occurs pervasively throughout metasedimentary xenoliths and the country rocks in the Northwestern Border area of the Complex, and also in gabbros along the margins of granitic dikes and semi-ductile shear planes. Apple-green epidote alteration occurs mostly along the contacts with the granitic dikes and in shear planes, with intense alteration having produced rocks composed of nearly pure epidote over widths of several meters (such as those observed in DDH L00-05). Albitization is less intense and is usually associated with areas of orange, hematitic alteration; but intense albitization does occur in rocks with intense epidote alteration. Orange, hematitic alteration and albitization are common, adjacent to narrow $(<1 \mathrm{~m}$ wide) granodiorite dikes. Chlorite commonly pseudomorphs secondary hornblende, and actinolite also replaces secondary hornblende. This alteration event was also accompanied by the formation of narrow $(<1 \mathrm{~cm})$ veins of quartz \pm chlorite \pm calcite \pm epidote. Very narrow carbonate veinlets are commonly accompanied by the obliteration of primary igneous textures and by the presence of pervasive carbonate alteration halos several centimeters in width. Narrow $(<1 \mathrm{~m})$ shear zones may also be filled with ankerite \pm pyrite.

\section{Copper-Nickel-Platinum-Group Elements Mineralization}

\section{Distribution of the Mineralization}

Copper-Ni-PGE mineralization is mostly restricted to leucogabbro (units 5a* and 5aa) in the Northwestern Border area of the Complex (Figs. 5 and 6). Mineralized leucogabbro bodies, such as the one which hosts the Main Showing, display northeast strikes with both southeast and northwest, steep to moderate dips (Fig. 6). These mineralized leucogabbro bodies always share a lower contact with unmineralized clinopyroxenite or melanogabbro (Fig. 6), with the location of $\mathrm{Cu}-\mathrm{Ni}$-PGE mineralization being focussed at the contact between the two units.
Diamond drill hole L-00-07, located $\sim 500$ m northeast of the Main Showing, intersected leucogabbro breccia with significant $\mathrm{Cu}-\mathrm{Ni}$-PGE mineralization, with mineralization occurring in both clasts and matrix suggesting that the mineralization was continuous during and after brecciation. High PGE contents were also observed in a magnetite-rich leucogabbro in DDH L00-03, which is significantly different in texture from the Main Showing sub-type (unit 5a*) leucogabbro (Fig. 6). The discovery of Cu-Ni-PGE mineralization in these rocks suggests that undiscovered mineralization may exist in other units of the Complex.

\section{Characteristics of the Cu-Ni-PGE Mineralization}

The Cu-Ni-PGE mineralization typically occurs as disseminated to blebby sulfides (locally representing up to 15 vol.\% of the rock) that comprise a mixture of chalcopyrite + pyrite \pm pyrrhotite + millerite \pm pentlandite. Chalcopyrite is the predominant metallic mineral, comprising greater than $40 \mathrm{vol} . \%$ of the sulfides. Typically, all sulfide minerals are surrounded by coarse-grained epidote \pm actinolitic amphibole (Figs. 7A and 7B), which gives the mineralized rock a characteristic very dark green color (Fig. 7A). Rare carbonate inclusions are also found in sulfide aggregates, and chlorite is common near the sulfide blebs.

\section{Geochemical Characteristics of the Cu-Ni-PGE Mineralization}

The Cu-Ni-PGE mineralization is characterized by consistently low $\mathrm{Pt} / \mathrm{Pd}$ of $\sim 0.20$ (Fig. $8 \mathrm{~A}$ ), and variable $\mathrm{Cu} / \mathrm{Ni}$ of between 5.6 and 0.1 (Fig. 8B) with an average value of 2.9. The enrichment of PGE is positively correlated with the enrichment of $\mathrm{Cu}$ (Fig. 8C) and $\mathrm{Ni}$ (Fig. 8D); consequently, the concentration of PGE in the Complex is related to the amount of $\mathrm{Cu}$ and $\mathrm{Ni}$ sulfides (Fig. 8E). The concentration of $\mathrm{Au}$ is also positively correlated with that of PGE (Fig. 


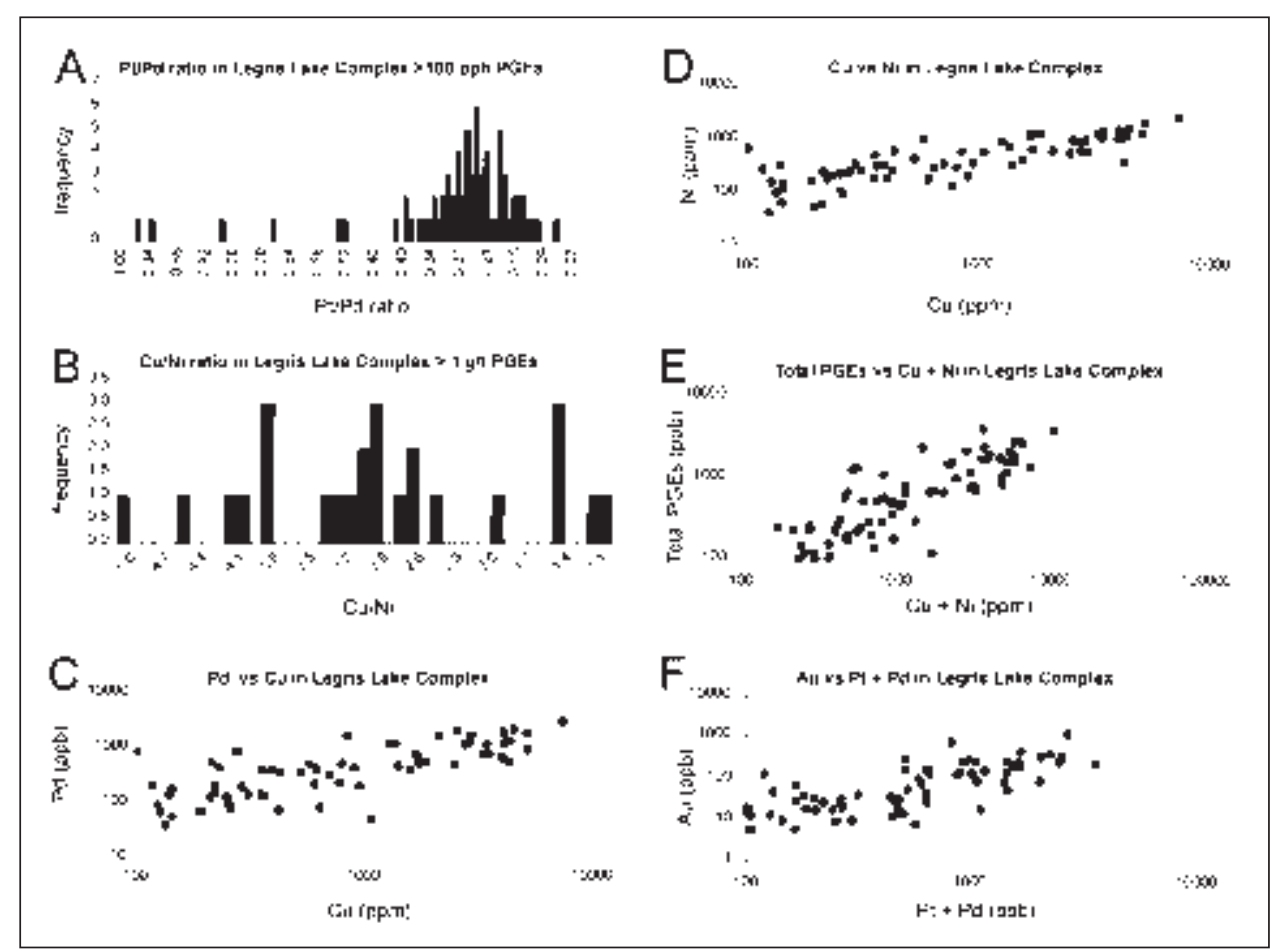

Fig. 8. (A) Histogram of the Pt:Pd ratios of Cu-Ni-PGE mineralization in the Legris Lake Complex. (B) Histogram of the $\mathrm{Cu}$ :Ni ratios of $\mathrm{Cu}-\mathrm{Ni}-\mathrm{PGE}$ mineralization in the Legris Lake Complex. (C) Plot of $\mathrm{Cu}$ vs $\mathrm{Pd}$ of $\mathrm{Cu}-\mathrm{Ni}$-PGE mineralization in the Legris Lake Complex. (D) Plot of $\mathrm{Cu}$ vs Ni of $\mathrm{Cu}-\mathrm{Ni}-\mathrm{PGE}$ mineralization in the Legris Lake Complex. (E) Plot of $\mathrm{Pt}+\mathrm{Pd}$ vs $\mathrm{Cu}+\mathrm{Ni}$ of $\mathrm{Cu}-\mathrm{Ni}-\mathrm{PGE}$ mineralization in the Legris Lake Complex. (F) Plot of Au vs Pt+Pd of Cu-Ni-PGE mineralization in the Legris Lake Complex.

$8 \mathrm{~F})$. The values of $\mathrm{Au} /(\mathrm{Pt}+\mathrm{Pd})$ display considerable scatter, ranging from 0.97 to 0.02 with an average of 0.13 .

Ten rock samples containing greater than $1 \mathrm{~g} / \mathrm{t} \mathrm{com-}$ bined PGE were selected for Rh analysis. The Cu-rich samples $(\mathrm{n}=9)$ from DDH L00-01, $-02,-04,-07$, and -08 all contain low concentrations of Rh $(<40 \mathrm{ppb})$; however, one sample at depth (from the interval between $285.18 \mathrm{~m}$ and $285.95 \mathrm{~m}$ in DDH L00-03) yielded a much higher concentration of Rh (520 ppb), together with values of $910 \mathrm{ppb} \mathrm{Pd}$, and $185 \mathrm{ppb} \mathrm{Pt}, 18 \mathrm{ppb} \mathrm{Au}, 103 \mathrm{ppm} \mathrm{Cu}$, and $720 \mathrm{ppm} \mathrm{Ni}$. This Rh-rich sample is composed of coarse-grained leucogabbro, but is distinct from the unit 5a* leucogabbro, in that it contains abundant magnetite and only trace amounts $(<0.25$ vol.\%) of sulfide (Fig. 9): features that suggest the possible presence of a second type of PGE mineralization in the Legris Lake Complex.

\section{Geophysical Characteristics}

The Legris Lake Complex displays a highly variable geophysical signature reflecting its heterolithic composition. The Complex is covered by a 1:63 360 scale aeromagnetic survey completed by the O.D.M - G.S.C. in 1962, and has recently undergone ground-based magnetometer and induced polarization surveys, which were conducted on the western side of the intrusion during the 2000 exploration programs.

\section{Magnetic Survey}

Leucogabbros (units $5 \mathrm{a}^{*}$ and 5aa) are commonly magnetic, the melanogabbros (units 5C and 5D) are strongly magnetic, the ultramafic rocks are always strongly magnetic, and the heterolithic breccia (unit 4a) is non-magnetic. Country rocks, such as granodiorite, metasedimentary rocks, and basalt are typically non-magnetic. The ground magnetometer survey illustrated the heterogeneous distribution of various rocks in the Northwestern Border area of the Complex. There are several areas, where rocks on surface

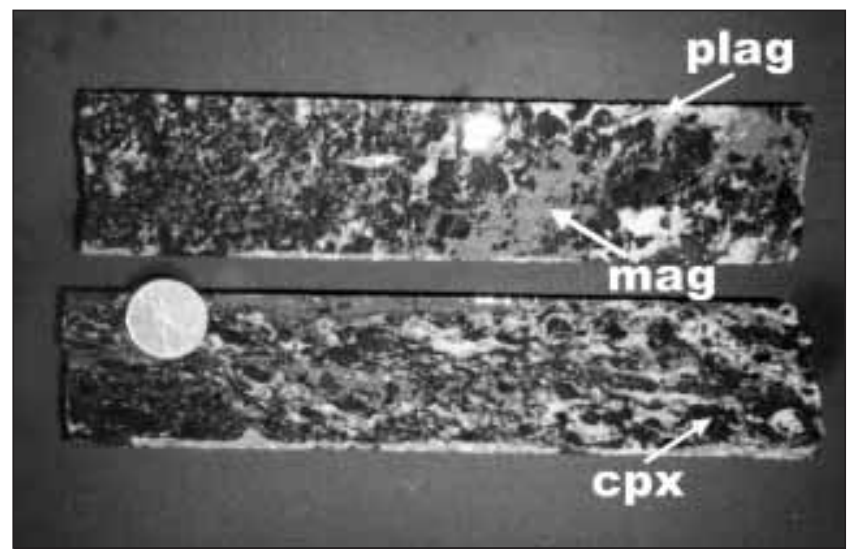

Fig. 9. Magnetite-rich leucograbbro sample from DDH L00-03 containing high $\mathrm{Rh}$ and low $\mathrm{Cu}$. plag = plagioclase, $\mathrm{cpx}=$ clinopyroxene, mag $=$ magnetite . 
contain up to 5 vol. $\%$ magnetite, that did not produce high magnetic anomalies; whereas, other areas with no magnetite produced strong magnetic anomalies. This made magnetic survey useful in identifying unexposed igneous bodies, although it is difficult to define lithological contacts using the data. Magnetite contents vary within a unit and magnetite is commonly obliterated by hematitic alteration. For example, mineralized leucogabbro (unit 5a* and 5aa) can be non-magnetic, such as in the case at the Main Showing area and in drill holes DDH L00-01, L00-02; or it can be strongly magnetic such as ii the case in drill holes DDH L00-04 and DDH L00-08.

\section{Induced Polarization Survey}

Chargeability highs and resistivity lows correspond to stronger magnetic anomalies, indicating that magnetite is the predominant conductor in the Legris Lake Complex. The majority of the chargeability anomalies are associated with high resistivities, suggesting the possible reduction in porosity of rocks by carbonate and/or epidote-albite alteration; but the magnitude of the anomalies does not necessarily correspond to the intensity of the alteration. Caution must be used when interpreting resistivity data as they display a strong tendency to follow topographic variations, creating lows in swamp areas and highs on bedrock ridges. Leucogabbro (unit $5 \mathrm{a}^{*}$ ) is commonly associated with high resistivities in the order of $710000 \mathrm{ohm}-\mathrm{m}$. Variations in resistivity, chargeability, and magnetic anomalies in leucogabbro (unit 5ab) are most likely explained by the different intensities of "hematitic" alteration at the expense of magnetite. All of the $\mathrm{Cu}-\mathrm{Ni}$-PGE mineralization discovered to date (e.g., the area of the Main Showing) is associated with at least moderate chargeabilities. The Cu-Ni-PGE mineralization in drill holes DDH L00-04, - 08, and -07 is located on the margin of an area with strong magnetic/chargeability anomalies; whereas, the drill holes DDH L00-09, -10, and -11, in the center of the same magnetic/chargeability anomalies, failed to intersect any significant mineralization. Most chargeability anomalies increase with increasing depth.

\section{Discussion}

\section{Cu-Ni-PGE Mineralization}

The source for the $\mathrm{Cu}, \mathrm{Ni}$, and PGE in the mineralization of the Legris Lake Complex is considered to be the parental magmas to the Complex itself, but the mineralization process is less certain. There are several possible processes that played a role in the formation of the mineralization:

1. late-stage saturation of sulphur in the parental magma;

2. fractionation of $\mathrm{Ni}, \mathrm{Cu}$, and $\mathrm{PGE}$ in sulfide liquid in the magma;
3. transportation of PGE from solidifying magma by aqueous fluids that originated from the parental magmas (i.e., deuteric fluids; for example, see Lavigne and Michaud, this volume); and

4. leaching of PGE from the solidified intrusions by aqueous fluids that originated from an external source/s (for example, see Molnár and Watkinson, this volume).

Copper, Ni, and PGE are preferentially incorporated into an immiscible sulphur liquid upon saturation of sulfur in a silicate melt. This model (model 1) is considered to be the main cause of the PGE mineralization in Sudbury-type, Ni-sulfide ore deposits. Such a magmatic process could also explain the formation of mineralization in the Legris Lake Complex. If this was indeed the main process for mineralization in the Complex, high contents of $\mathrm{Cu}$ and $\mathrm{Pd}$ relative to $\mathrm{Pt}$ and $\mathrm{Ni}$ require the late-stage saturation of sulfur in the parental magmas. Iridium, $\mathrm{Os}, \mathrm{Ru}$, and $\mathrm{Ni}$ are compatible with early crystallizing silicate minerals in comparison to $\mathrm{Pd}, \mathrm{Pt}, \mathrm{Au}$, and $\mathrm{Cu}$. Therefore, magmas are enriched in $\mathrm{Pd}, \mathrm{Pt}, \mathrm{Au}$ and $\mathrm{Cu}$ relative to Ir, Os, Ru, and Ni during fractional crystallization (Fig. 10). Since $\mathrm{Pd}$ is more incompatible than $\mathrm{Pt}$, the $\mathrm{Pd} / \mathrm{Pt}$ increases during fractional crystallization. Sulfur saturation may have been prompted by a volume reduction of the melt by crystallization, and also the incorporation of silica and/or sulfide from surrounding metasedimentary rocks. The incorporation of silica and sulfur into the melt from metasedimentary host rocks is supported by the presence of abundant metasedimentary rock fragments in the Northwestern Border area of the Legris Lake Complex. Brecciation and multiple magma pulses contributed to the efficient scavenging of PGE from the silicate magmas, causing a very high effective ratio of silicate to sulfide melt (R factor; Theriault et al., 1997) for the sulfide. The resulting PGE- and Cu-rich sulfide melt would thus be concentrated in leucocratic phases of the Complex.

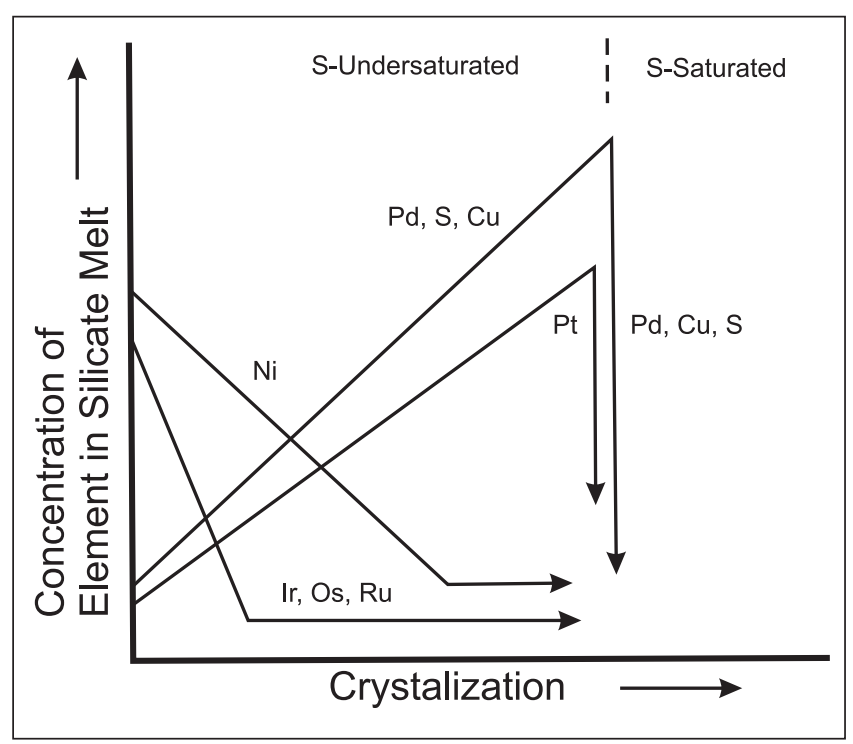

Fig. 10. Diagram illustrating the effects of a fractionating magma before and after sulfur saturation on $\mathrm{Cu}-\mathrm{Ni}$-PGE partition coefficients (modified after Lightfoot and Keays, 1995). 


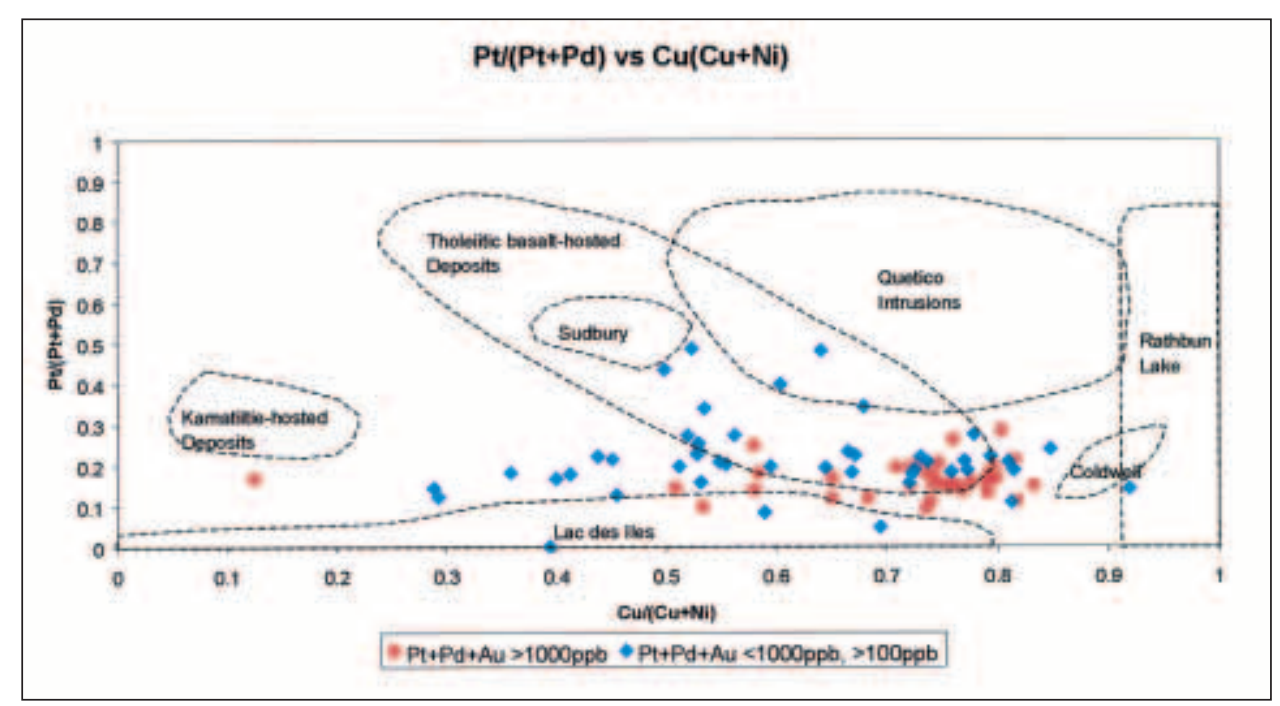

Fig. 11. Plot of $\mathrm{Cu} /(\mathrm{Cu}+\mathrm{Ni})$ vs $\mathrm{Pt} /(\mathrm{Pt}+\mathrm{Pd})$ of $\mathrm{Cu}-\mathrm{Ni}-\mathrm{PGE}$ mineralization in the Legris Lake Complex compared to other Cu-Ni-PGE deposits. Modified after MacTavish (1999) and Michaud (1998).

The enrichment of $\mathrm{Pd}$ and $\mathrm{Cu}$ may also take place within sulfide liquid since $\mathrm{Fe}, \mathrm{Ni}$, Os, Ir, and $\mathrm{Ru}$ are preferentially incorporated in an early monosulfide solution (Barnes et al., 1997). This process (model 2) is discounted as having contributed substantially to the $\mathrm{Cu}$ - and $\mathrm{Pd}$-rich mineralization in the Legris Lake Complex because sulfide minerals represent only a minor component of the intrusive rocks of the Complex.

Chlorine-rich aqueous fluids can also affect the separation of $\mathrm{Pd}$ and $\mathrm{Cu}$ from other PGE and Ni because the former elements are more soluble in aqueous fluids (Jaireth, 1992; Sassani and Shock, 1990; Meurer et al., 1999). Therefore, the high contents of $\mathrm{Cu}$ and $\mathrm{Pd}$ in the Legris Lake Complex, relative to the other metals, suggest the possible transport and enrichment of $\mathrm{Cu}$ and $\mathrm{Pd}$ by aqueous fluids (models 3 and 4). This possibility is supported by the common occurrence of breccias in the Complex, and by the hydrous alteration that is typically associated with the Cu-Ni-PGE mineralization.

There is, however, no clear evidence for extensive hydrothermal activity involving fluid of external origin. The distribution of breccias and alteration indicates that hydrothermal activity was confined to within the Complex. Therefore, the leaching of PGE by external fluids (model 4) is also discounted. Local transport of PGE by magmatic (deuteric) fluids (model 3) is supported by the common occurrence of epidote surrounding sulfide blebs and disseminated sulfides (Fig. 7), by the hydrofracturing of the wall rocks surrounding leucogabbro (unit $5 \mathrm{a}^{*}$ ), and by the presence of varitextured leucogabbro.

\section{Comparison with Other Copper-Nickel and Platinum- Group-Element Deposits}

The Legris Lake Complex contains a wide range of igneous rock types, from leucogabbro to dunite in composi- tion; with high degrees of brecciation of the igneous rocks being associated with multiple magma injection. The breccias, although metasediment-rich, share many similarities in lithology and texture with the heterolithic gabbro described by Lavigne and Michaud (this volume), which surrounds the East gabbro and hosts the Twilight and Roby zones at the Lac des Iles mine. The Northwestern Border area of the Legris Lake Complex is also similar in nature to the $\mathrm{Cu}-\mathrm{Ni}$ PGE-rich breccias lining the western contact of the River Valley intrusion of the East Bull Lake Suite of mafic-ultramafic intrusions near Sudbury, Ontario. However, the restriction of $\mathrm{Cu}-\mathrm{Ni}-\mathrm{PGE}$ mineralization in leucogabbro near the contact with underlying ultramafic rocks is a feature that also shares similarities to stratiform-style mineralization in large layered, mafic-ultramafic complexes.

The geochemical characteristics of the Cu-Ni-PGE mineralization of the Legris Lake Complex plot mostly in the lower part of the tholeiitic-hosted deposits field (Fig. 11). The data also plots close to the mineralized rocks of the Lac des Iles deposit, but in a slightly more Pt-rich part of the diagram, and near the values for thr Rathbun Lake deposit, which is considered to be of hydrothermal origin (Rowell, 1984).

\section{Effective Exploration Techniques for this Style of Mineralization}

The low to moderate sulfide content of the PGE mineralization in the Legris Lake Complex does not produce strong geophysical anomalies. Because the PGE mineralization occurs in both magnetite-rich and magnetite-poor leucogabbro (unit $5 \mathrm{a}^{*}$ ), it is therefore recommended that geological mapping and trenching should be combined with geophysical surveys before the commencement of diamond drilling. Induced polarization, and ground-based magnetometer surveys were useful in outlining possible areas of mineralization 
Table 1. Representative $\mathrm{Cu}, \mathrm{Ni}$, and PGE concentration in high-grade drill core samples

\begin{tabular}{|c|c|c|c|c|c|c|c|c|c|c|}
\hline \multirow[t]{2}{*}{ Hole } & \multicolumn{2}{|c|}{ Grid Location } & \multirow{2}{*}{$\begin{array}{l}\text { Core } \\
\text { Length } \\
\text { (m) }\end{array}$} & \multirow{2}{*}{$\begin{array}{c}\text { Interval } \\
\text { Length } \\
\text { (m) }\end{array}$} & \multirow{2}{*}{$\begin{array}{c}\text { PGE } \\
(\mathbf{P d}+\mathbf{P t}+\mathbf{A u}) \\
(\mathrm{g} / \mathrm{t})\end{array}$} & \multirow{2}{*}{$\begin{array}{c}\text { Pd } \\
(\mathrm{g} / \mathrm{t})\end{array}$} & \multirow{2}{*}{$\begin{array}{c}\mathbf{P t} \\
(\mathrm{g} / \mathrm{t})\end{array}$} & \multirow{2}{*}{$\underset{(\mathrm{g} / \mathrm{t})}{\mathrm{Au}}$} & \multirow{2}{*}{$\begin{array}{l}\mathbf{C u} \\
(\%)\end{array}$} & \multirow{2}{*}{$\begin{array}{c}\mathbf{N i} \\
(\%)\end{array}$} \\
\hline & North & East & & & & & & & & \\
\hline L00-01 & $95+55 \mathrm{~N}$ & $94+85 \mathrm{E}$ & $35.75-42.00$ & 6.25 & 0.88 & 632 & 171 & 75 & 0.17 & 0.09 \\
\hline and & & & $51.30-63.30$ & 12.00 & 0.86 & 609 & 157 & 99 & 0.22 & 0.10 \\
\hline Including & & & $51.30-56.60$ & 5.30 & 1.10 & 797 & 176 & 132 & 0.34 & 0.15 \\
\hline and & & & $60.55-61.80$ & 1.25 & 1.78 & 1170 & 412 & 201 & 0.35 & 0.11 \\
\hline L00-02 & $95+55 \mathrm{~N}$ & $95+10 \mathrm{E}$ & $51.60-62.30$ & 10.70 & 1.62 & 1217 & 237 & 171 & 0.32 & 0.09 \\
\hline Including & & & $52.70-56.10$ & 3.40 & 1.93 & 1543 & 260 & 130 & 0.34 & 0.13 \\
\hline Including & & & $54.25-54.70$ & 0.45 & 3.75 & 3150 & 386 & 214 & 0.75 & 0.27 \\
\hline and & & & $56.90-62.30$ & 5.40 & 1.82 & 1315 & 283 & 222 & 0.33 & 0.09 \\
\hline Including & & & $56.90-60.00$ & 3.10 & 2.66 & 1947 & 404 & 312 & 0.47 & 0.14 \\
\hline L00-04 & $95+50 \mathrm{~N}$ & $98+00 \mathrm{E}$ & $3.70-8.40$ & 4.70 & 0.87 & 187 & 161 & 519 & 0.27 & 0.07 \\
\hline Including & & & $6.90-8.40$ & 1.50 & 1.15 & 655 & 260 & 238 & 0.41 & 0.10 \\
\hline L00-07 & 10100 & 9550 & $43.92-48.84$ & 4.92 & 1.21 & 0.957 & 0.152 & 0.097 & 0.13 & 0.04 \\
\hline Including & & & $46.73-48.84$ & 2.11 & 2.04 & 1.599 & 0.246 & 0.193 & 0.26 & 0.06 \\
\hline L00-08 & 9550 & 9900 & $18.74-28.69$ & 9.95 & 3.16 & 2.037 & 0.410 & 0.712 & 0.42 & 0.13 \\
\hline Included & & & $25.33-26.69$ & 1.36 & 3.40 & 2.550 & 0.460 & 0.394 & 0.46 & 0.15 \\
\hline and & & & $57.24-61.04$ & 3.80 & 2.92 & 1.938 & 0.342 & 0.643 & 0.29 & 0.11 \\
\hline and & & & $72.26-75.26$ & 3.00 & 1.88 & 1.322 & 0.272 & 0.289 & 0.33 & 0.10 \\
\hline L00-03ext & 9550 & 9975 & $223.92-228.60$ & 4.68 & 0.248 & 0.191 & 0.046 & 0.011 & 0.021 & 0.013 \\
\hline and & & & $227.20-282.22$ & 4.63 & 0.344 & 0.272 & 0.047 & 0.025 & 0.072 & 0.045 \\
\hline and & & & $284.37-287.82$ & 3.45 & 0.331 & 0.227 & 0.046 & 0.06 & 0.010 & 0.030 \\
\hline Including & & & $285.18-285.95$ & 0.77 & 1.113 & 0.910 & 0.185 & 0.018 & 0.010 & 0.070 \\
\hline
\end{tabular}

at Legris Lake. Chargeability highs associated with $\mathrm{Cu}-\mathrm{Ni}$ PGE mineralization are not very strong in the Complex and the mineralization typically occurs on the margin, as opposed to the center, of such magnetic/chargeability highs.

Prospecting remains an effective technique for exploration. In addition, careful investigation of weakly anomalous samples ( $>10 \mathrm{ppb} \mathrm{Pd}$ ) is necessary due to the unpredictable distribution of the mineralization and narrow halos associated with the PGE mineralization. This is best exemplified by the occurrence of a $36 \mathrm{ppb} \mathrm{Pd}$ sample on surface, whose location became the collar location of DDH L00-07, which subsequently intersected $2.11 \mathrm{~m}$ of $1.6 \mathrm{~g} / \mathrm{t} \mathrm{Pd}$ at depth. Due to the very low combined PGE concentration in weakly mineralized samples, it is important to use only $\mathrm{Pd}$ and not $\mathrm{Pt}+\mathrm{Pd}$ or total PGE, in outlining anomalous areas. This is due to slightly high Pt values in ultramafic rocks compared to gabbroic rocks and local weakly anomalous $\mathrm{Au}$ mineralization associated with retrograde alteration.

\section{Conclusion}

The Legris Lake Complex hosts significant $\mathrm{Cu}-\mathrm{Ni}$ PGE mineralization with several long $(>5 \mathrm{~m})$ drill-core intersections containing greater than $1 \mathrm{~g} / \mathrm{t}$ combined PGE (Table 1). The mineralization is predominantly Pd- and $\mathrm{Cu}$-rich, with lesser amounts of $\mathrm{Pt}, \mathrm{Au}$, and Ni. It is considered to be of late magmatic origin, with local enhancement by magmatic-hydrothermal activity. The mineralization is confined to leucogabbro (i.e., Main Showing sub-type, unit $5 \mathrm{a}^{*}$; and varitextured sub-type, unit $5 \mathrm{aa}$ ) directly overlying clinopyroxenite. The mineralized leucogabbro occurs within a $2 \mathrm{~km}$ long by $600 \mathrm{~m}$ wide breccia zone in the Northwestern Border area of the
Legris Lake Complex. This breccia zone is more than sufficient in size to host a Cu-Ni-PGE deposit amenable to economic development via open pit mining. The breccia zone continues at depth as is indicated by the results of magnetometer surveys and diamond drilling. Furthermore, the mineralization may extend along the northern contact of the Complex, in an area covered by thick overburden, where several chargeability anomalies and bodies of leucogabbro (unit 5a*) remain untested by diamond drilling. The center of the Complex consists of homogeneous leucogabbro (unit 5ab) and does not appear to be a favorable host for $\mathrm{Cu}-\mathrm{Ni}$-PGE mineralization. The Northeastern Border area has received little exploration and has a potential to host significant $\mathrm{Cu}-\mathrm{Ni}$-PGE mineralization as it shows more extensive and stronger magnetic anomalies than the Northwestern Border area.

\section{Acknowledgments}

We would like to thank Donald Bubar (president, Avalon Ventures Ltd.), Ian Campbell (former vice-president of exploration, Avalon Ventures Ltd., currently vice-president of exploration of Temex Resources Corp.), and Karen Rees (general manager, Avalon Ventures Ltd.) for access to the property and company reports, their constructive comments, and for allowing the publication of this paper.

\section{References}

AYRES, L.D., 1978. Metamorphism in the Superior Province of northwestern Ontario and its relationship to crustal development. In Metamorphism in the Canadian Shield. Geological Survey of Canada, Paper 78-10, p. 25-36. 
BARNES, S., MAKOVICKY, E., MAKOVICKY, M., ROSE-HANSEN, J. and KARUP-MOLLER, S., 1997. Partition coefficients for $\mathrm{Ni}, \mathrm{Cu}, \mathrm{Pd}, \mathrm{Pt}, \mathrm{Rh}$, and $\mathrm{Ir}$ between monosulfide solid solution and sulfide liquid and the formation of compositionally zoned $\mathrm{Ni}-\mathrm{Cu}$ sulfide bodies by fractional crystallization of sulphide liquid. Canadian Journal of Earth Sciences, 34, p. 366374.

BLACKBURN, C.E., JOHN, G.W., AYERS, J.A. and DAVIS, D.W., 1991. Wabigoon Subprovince. In Geology of Ontario. Ontario Geological Survey, Special Volume 4, Part 1, p. 303-381.

DAVIES, J.C., 1965. Geology of the High Lake-Rush Bay area, District of Kenora. Ontario Department of Mines, Geological Report 41, 57 p.

DAVIS, D.W. and EDWARDS, G.R., 1986. Crustal evolution of Archean rocks in the Kakagi Lake area, Wabigoon Subprovince, Ontario as interpreted from high precision $\mathrm{U}-\mathrm{Pb}$ geochronology. Canadian Journal of Earth Sciences, 23, p. 182-192.

DAVIS, D.W., BLACKBURN, C.E. and KROGH, T.E., 1982. Zircon U-Pb ages from the Wabigoon-Manitou Lakes region, Wabigoon Subprovince, northwest Ontario. Canadian Journal of Earth Sciences, 19, p. 254-266.

EDWARDS, G.R. and DAVIS, D.W., 1984. Petrogenesis and metallogenesis of the Atika-Lawrence volcanic-plutonic terrain. In Geoscience Research Grant Program. Summary of Research 1983-1984, Ontario Geological Survey, Miscellaneous Paper 121, p. 222-239.

JARIETH, S., 1992. The calculated solubility of platinum and gold in oxygen-saturated fluids and the genesis of platinum-palladium and gold mineralization in the unconformity-related uranium deposits. Mineralium Deposita, 27, p. $42-54$.

KAYE, L., 1969. Geology of the Eayrs Lake - Starnes Lake Area, District of Thunder Bay. Ontario Department of Mines, Geological Report 77, 29 p. Accompanied by Map 2171, scale 1:63360.

LAVIGNE, M.J. and MICHAUD, M.J., 2002. Geology of North American Palladium Ltd.'s Roby Zone deposit, Lac des Iles. Exploration and Mining Geology, this volume, p. 1-17.

LIGHTFOOT, P.C. and KEAYS, R.R., 1995. New approaches in targeting giant magmatic Ni-Cu-PGE deposits in Ontario. Short Course Notes, Ontario Geological Survey, p. 13.

MacTAVISH, A.D., 1999. The Mafic-Ultramafic Intrusions of the Atikokan-Quetico Area Northwestern Ontario. Ontario Geological Survey, Open File Report 5997.

MEURER, W.P., WILLMORE, C.C. and BOUDREAU, A.E., 1999. Metal redistribution during fluid exsolution and migration in the Middle Banded Series of the Stillwater Complex, Montana. Lithos, 47, p. 143-156.

MICHAUD, M.J., 1998. The Geology, Petrology, Geochemistry and Platinum-Group Element-Gold-Copper-Nickel Ore Assemblage of the Roby Zone, Lac des Iles MaficUltramafic Complex, Northwestern Ontario. M.Sc. thesis, Lakehead University, Thunder Bay, 62 p.
MOLNÁR, F. and WATKINSON, D.H., 2002. Fluid-inclusion data for vein-type $\mathrm{Cu}-\mathrm{Ni}-\mathrm{PGE}$ footwall ores, Sudbury Igneous Complex and their use in establishing an exploration model for hydrothermal PGE-enrichment around mafic-ultramafic intrusions. Exploration and Mining Geology, this volume, p. 125-142.

O.D.M. - G.S.C., 1962. Lac des Milles, Thunder Bay District. Ontario Department of Mines - Geological Survey of Canada, Aeromagnetic Survey Series, Map 2099G, Scale 1:63360.

PETTIGREW, N.T., 2000. Report on 1999-2000 exploration Legris Lake palladium-platinum property. Avalon Ventures Ltd. / Starcore Resources Ltd. Joint Venture. Company Report.

PETTIGREW, N.T., 2002. Report on 2001-2002 exploration Legris Lake palladium-platinum property. Avalon Ventures Ltd. / Starcore Resources Ltd. / Placer Dome CLA Limited Joint Venture. Company Report.

PETTIGREW, N.T. and HATTORI, K.H., 2002. Palladiumcopper-rich platinum-group element mineralization in Legris Lake mafic-ultramafic complex, Western Superior Province, Canada. Transactions of the Institution of Mining and Metallurgy (Section B: Applied Earth Science), 111, p. B46-B57.

POULSEN, K.H., BORRADAILE, G.J. and KEHLENBECK, M.M., 1980. An inverted Archean succession at Rainy Lake, Ontario. Canadian Journal of Earth Sciences, 17, p. 1358-1369.

PYE, E.G. and FENNWICK, K.G., 1964. Atikokan-Lakehead sheet. Ontario Department of Mines, Compilation Series, Map 2065, Scale 1:253400.

ROWELL, W.F., 1984. Platinum-Group Elements and Gold in the Wanapitei Nipissing-type Intrusions, Northeastern Ontario. M.Sc. thesis, University of Western Ontario, London, $87 \mathrm{p}$.

SASSANI, D.C. and SHOCK, E.L., 1990. Speciation and solubility of palladium in aqueous magmatic-hydrothermal solutions. Geology, 18, p. 925-928.

SUTCLIFFE, R.H., 1986. Regional Geology of the Lac des Iles Area, District of Thunder Bay. In Summary of Field Work and Other Activities 1986. Ontario Geological Survey, p. 70-75. Ontario Geological Survey, Miscellaneous Paper 132, p. 435.

SUTCLIFFE, R.H. and SMITH, A.R., 1988. Precambrian Geology of the Plutonic Rocks in the Lac des Iles - Tib Lake Area, District of Thunder Bay. Ontario Geological Survey, Map P. 3098, Geological Series — Preliminary Map Scale 1:50000.

SUTCLIFFE, R.H., SWEENY, J.M. and EDGAR, A.D., 1989. The Lac des Iles complex, Ontario: Petrology and platinum-group elements mineralization in an Archean mafic intrusion. Canadian Journal of Earth Sciences, 26, p. 14081427.

SWEENY, J.W. and SUTCLIFFE, R.H., 1986. Geology and platinum group element mineralization of the Roby Zone, Lac des Iles complex. In Summary of Field Work and Other Activities 1986. Ontario Geological Survey, Miscellaneous Paper 132, p. 82-84. 
THERIAUlT, R.D., BARNES, S. and SEVERSON, M.J., WHITTAKER, P.J., 1980. Chromite deposits in Ontario. 1997. The influence of country-rock assimilation and silicate to sulfide ratios ( $\mathrm{R}$ factor) on the genesis of the Dunka Ontario Geological Survey, Open File Report 5360, 152 p. Road Cu-Ni-platinum-group element deposit, Duluth Complex, Minnesota. Canadian Journal of Earth Sciences, 34, p. 375-389. 